\title{
Solving simultaneous risk equations: waste water recycling and fresh water sustainability in an arid continent
}

\author{
G. K. Smith ${ }^{1}$ \& A. Smith ${ }^{2}$ \\ ${ }^{1}$ School of International Studies, University of South Australia \\ ${ }^{2}$ Clean Ocean Foundation, Australia
}

\begin{abstract}
Two separate sets of entrenched environmental mal-practices in Australia have created serious health risk issues. The risk equations are becoming clearer and are interlinked. Solving one of these equations can assist in solving the other. Equation 1: Major Australian cities have dealt with the growing human and industrial waste water flows produced over the last century of growth by utilising coastal proximity and piping partially treated effluent into the oceans. As the volume and toxicity of the outfalls has multiplied, so have adverse health effects. Equation 2: The mainly European settlers of an arid continent increased their fresh water consumption at a prodigious rate. All major Australian cities are in water supply crisis and irrigations schemes and depleted rivers threaten agricultural sustainability. Tradeable water rights are to be granted to farmers but it has become potentially unaffordable for governments to buy back sufficient water rights to restore major river flows. Solutions: The Clean Ocean Foundation established the campaign to "close ocean outfalls" and invest in advanced technology recycling of all waste water to standards suitable for an array of agricultural and industrial uses, without health risks. Such an investment, which would be well supported by urban populations, takes the pressure from river systems and assists the affordability of water for farmers, industry, and for environmental buy-backs schemes alike.
\end{abstract}

Keywords: water recycling, water policy, environmental risk, environmental campaigns, Australia. 


\section{Introduction}

Two apparently separate sets of entrenched water practices in Australia have created severe environmental, economic and social problems, and sets of risk equations whose interactive dimensions have only recently begun to be identified. Both sets of risk issues have struggled to impact on the public policy process, but new political and policy dynamics are developing from local community and elite scientific activism. This paper looks at the linkages between two initially separate sets of issues, and how awareness of health risks of waste water disposal at the local community level are interacting with the science-led debate about the environmental risks of unsustainable water usage in the agricultural and urban economy. The idea of a single water cycle has real policy implications which have begun to be explored: solutions in waste water recycling will contribute to solutions to the highly stressed state of rivers and groundwater.

The more familiar Australian story is about the diversion of water from fragile river systems to support the demands of urban and rural economies: how the European occupants of the arid continent of Australia increased fresh water consumption at a prodigious rate, especially since the second half of the last century.

A less familiar story, or one certainly less discussed in polite society and influenced by cultural taboos, is about how major Australian cities have dealt with the growing human and industrial waste water flows from the last 60 years of growth - by utilising coastal proximity and piping untreated or partially treated effluent into the oceans. With all of Australia's major cities and most of its minor cities located on or near the coast, this was the "lucky country" version of urbanisation and industrialisation. Where many other countries used their rivers for this purpose, Australians could put most of the waste water further out of sight and mind into the oceans, and this continued through into the $21^{\text {st }}$ century. But as the volume and toxicity of the ocean outfalls have increased remorselessly, so have the documented cases of adverse environmental and health effects, and concern for unmeasured hazards. The visible plumes of pollutants have increased, shocking not only the citizens of Sydney at Bondi beach, but also those of Melbourne, at the equally iconic surf beach Gunnamatta (a Koori word for beach and sand hills).

Each of these narratives of risk is explored and the potential links between them are examined in the Australian context, together with an analysis of the different forms of political activism for policy change. Advanced waste water treatment which produces water with potential for recycling has become urgent for its own set of growing health risk reasons: there is no safe ocean dump for such a dangerous cocktail of pollutants. The economic costs of effective and sustainable solutions for the rivers may be partly offset by the potential for water recycling from the ocean waste outfalls to meet specified industrial, agricultural and domestic water needs. The risk investigation needs to be comprehensive, open, and with an appropriate sense of urgency - so that the economic investments, from public sector infrastructure and private sector policy settings, 
can be focused and implemented without the procrastination that accompanies partial approaches.

\section{Risk equation A: the emerging health crisis of ocean waste outfalls}

The planning mindset in Australia that has led to the creation of an estimated 143 ocean waste water outfalls was no different to that which generally accompanied the growth of cities in the industrial revolution, and which accompanies the rapid growth of cities in parts of the developing world today. The water task for the narrowly focused city planner was/is to bring in potable or safe water in for human and industrial uses, get rain water drained off the streets to mitigate flooding, and send sewage waste somewhere beyond the city limits. A comprehensive sewerage system was a matter of pride in engineering accomplishment and urban modernity, solving the great public health crises that the open sewer represented, both in reality, and also in folk memory of plague and pestilence. It was as though the very act of moving the waste somewhere else was such an achievement that the matter of where it went and what was happening there was for smaller minds.

In the Australian states, large public utilities, Boards of Works, operated through the $20^{\text {th }}$ century. They built the system and the state enforced the laws of sewerage on property owners, with pipes inscribed on land titles and checked on sale of property. The initial perception of risk was very simple: the waste removal system had transformed a high health risk system into a no-risk one, and the community's champions were the engineers who build the pipes to take it all away. Sydney and Melbourne took slightly different paths to the same endpoint over the twentieth century as urban and industrial growth continued. Sydney, being more proximate to the ocean, chose largely to pour it straight in. Melbourne, on an extensive bay, and with a more socially progressive selfimage, developed a major sewage farm for 'treated' effluent around a significant part of the bay near the town of Werribee, to grow pastures to raise cattle. But, overwhelmed by growing volume, and disturbed that much still flowed or overflowed into the bay near the city, the Melbourne and Metropolitan Board of Works in the 1960s set about building the great pipe to the ocean to get to the norisk final solution that the vastness of the oceans seemed to offer. Community opposition at the time saw the planned pipe moved from Westernport Bay (on the south-eastern side of the city) to Gunnamatta, much further south on the ocean. To allay concerns of landholders and ocean users in the area of the outfall, it was claimed that new treatment technologies installed on the way to the ocean would deal with all pollution issues [2]. At the opening of the major treatment plant for the pipe in 1975, the Board's Chairman is reputed to have declared that the water from the plant was "good enough to drink".

This completion of the pipe marked the transition by a public body from engineering works utility to political spin agent (to the point of outright denial), in the face of concerns over emerging health risks. It foreshadowed an inertia, and a defensive politicisation, which 33 years later, in 2005, saw the same pipe 
with little improved treatment plant producing nothing more than what is defined in Australia as Class C level of treatment [3], while the evidence of risks, identified, probable and possible has steadily mounted [4].

Over this period there have been dramatic changes in the volume and composition of the outfall. Focussing on Melbourne as illustrative case study, the volume of outfall has expanded rapidly with population and industrial growth, leading to a typical discharge at Gunnamatta of $450 \mathrm{ML}$ per day. This was a greater daily flow that that typical of the Murray River in its course. Furthermore, and of crucial importance to environmental health risk, the composition of the outfall continued to change as industrial, domestic and human pharmaceutical practices changed: new chemical and bio-chemical components waste entered the waste system. Some of the practices were shaped by government policies; industries including hospitals \& abattoirs wanting to dispose of their waste through the sewerage system were able to do so through entering trade waste agreements with the Environment Protection Agency, and paying a fee. These "licenses to pollute" represent the demise of agencies set up after the first wave of environmentalism in the late 1960s, coopted into the normalised politics of pollution.

The general scientific literature on the array of health risks associated or potentially associated with various components of waste water and the potential for technologies to address these risks is growing rapidly. In Australia, the work of the Oz-AQUAREC team at University of Wollongong (a partner of the EC initiative for Integrated Concepts for Reuse of Upgraded Wastewater) provides an important clearing house [5]. Its 2005 conference on Integrated Concepts in Water Recycling focussed directly on issues of water quality and water usage options, and a previous one on A Triple Bottom Line Approach to Water Recycling explored not only the complex technical issues of water risk, but also the institutional and social settings that can inhibit or facilitate change.

Growing scientific awareness of the potential health risks has been met in some States with a degree of resistance by the institutions that evolved from the Boards of Works, now with contemporary names such as Melbourne Water and Sydney Water. These organisations, who once saw their duty as being to provided unlimited fresh water to the city at minimal cost, were in the most recent 5 years, demonstrating their new profile as water conservers, charging urban consumers ever more for their water and using the revenue to fund campaigns to create social pressure on individuals who wasted water, who were to be defined as "Water Wallies", thoughtless wasters. Most of these newly rebranded water authorities have been unable to focus sharply on the health risks of waste water disposal into the oceans, and on the issues of public and financial responsibility which these risks raise. Comprehensive studies on Australian ocean outfalls have generally been slow to develop, and there is little public confidence in the benchmarks being set by EPAs often reporting to the same Ministers as the water authorities, and sharing a budgetary allocation between them. There is a significant lag between identifying potential risk elements, developing a notion of acceptable levels and then monitoring for those levels and reporting in a meaningful way. 
The driver for change has come instead from community organisations [6]. These organisations have in turn been boosted by the expansion of human settlement and recreational activity to geographical areas near ocean outfalls. For Melbourne, the pipe was taken to Gunnamatta at the end of the once remote Mornington Peninsula in the 1970s. The Mornington Peninsula today is a leading region of wine-making, recreational activity and life-style settlement. The outfall is are no longer out of sight; and so no longer out of mind. The Clean Ocean Foundation [1] was originally by local surfers concerned about their health, and partly inspired by the UK group Surfers Against Sewerage. It has become intensely engaged in campaigning activities at the local, state and national levels, but deeply connected to a political base in the Mornington Peninsula

In the absence of sufficient testing by the water authorities, the Foundation began to conduct its own tests, with sampling identifying problematic bacteria and viruses e.g. enterococci, faecal coliforms, streptococci, hepatitis $\mathrm{C}$, and chemical contaminants e.g. N, P, phthalates, dioxins. Surveys of beach users identified numerous reported health problems e.g. throat, ear, gastric infections, viral meningitis and hepatitis, and a database of health reports was accumulated. The evidence was sporadic, ad hoc, indicative not conclusive - but sufficient to demonstrate the reality and potential of significant health risks.

The Clean Ocean Foundation developed a campaign over the last four years to contest the technology and politics of outfall inertia, creating a political dynamic for policy change. In response to the myriad of identified, probable, and possible health risks, it adopted the most challenging of all alternatives to the old pipe-it-to-the-ocean paradigm: a demand to commit to closing the pipe altogether in 10 years. This would allow time the time to identify, test and invest in recycling usable water for a range of purposes.

\section{Risk equation B: the crisis of fresh water supply in an arid country}

The exponential growth in water consumption over the last century, and in particular the last 40 years, was driven not only the rapid growth of cities based on the English suburban garden and American swimming pool, but ever expanding irrigation schemes which permitted and encouraged farmers to tap the rivers for irrigation projects oblivious to the consequences. As a result, all of Australia's major cities face fresh water crises of varying but growing proportions, as dams fail to provide the quantity of water required and with quality in sharp decline. On the agricultural side, irrigators' overuse of water has been at the expense of other rural interests, with damaged groundwater and rising salinity a persistent theme of scientific documentation [7]. The fate of the great Murray-Darling system is the most analysed, and it no longer carries enough water to keep its ocean entrance open without regular dredging.

Analysing and forecasting the state of rivers, groundwater, salinity and the total effect on sustainability requires the knowledge and skills of complex science. The pressure for change in water use policies has come principally from 
the environmental scientific community, and increasingly from it leaders, felt driven by the urgency of the situation to act in common to deliver a message on necessary changes. The unsustainability of the practices of damming and draining rivers was spelt out most recently in Blueprint for a National Water Plan, [8] the report of the "Wentworth Group" of eminent scientists to a meeting of all Australian state and federal governments. The Blueprint focused on three reforms:

1. Protecting river health and the rights of all Australians to clean usable water, prioritising environmental needs;

2. Establishing a national water entitlements and trading system, and funding the return of at least 100GL to the Murray river each year;

3. Engaging local communities to ensure a fair transition, including Environmental Water Trusts to manage stressed river systems

Initial public policy responses to the water supply crisis reflect the power and perceptions of different sectors. In the cities, the price increases and water saving campaigns of the water authorities achieved a degree of inevitable response from the public, who in their process of re-education were not at all engaged over the industrial, agricultural and wastewater issues and were led to believe that the full solution lay in their own profligate hands. In agricultural industry, where $70 \%$ of water consumption occurs, water was instead turned into a gift not a tax - farmers who had helped themselves to the rivers over the previous decades were to be given commercial water rights, and if governments now wished to "restore environmental flows", they would have to buy these rights from those farmers who had been given them. But it has become expensive for governments to buy back sufficient water rights to restore major river flows, with Quiggin estimating up to $\$ 3$ billion to restore the Murray River $[9,10]$. Rewarding those who have pursued the most unsustainable farming practices also appears to create a situation of moral hazard, which some fear might lead to further demands for governments to pay to cease other unsustainable practices such as excessive land clearing [11].

\section{Achieving change: contrasting campaign styles}

Damage to the rivers, with all its long term consequences, has become the focus of a scientific politics, characterised by increased activism of larger and larger groups of the most eminent scientists, based on rational principles of evidence and argument. Some of these scientists at times seem angry and baffled at the obduracy of the political and economic system, in the face of their compelling arguments. Ocean outfalls, with all their consequences, have by contrast, become the focus of community politics, characterised by a direct demands for policy change at the local/state level based on the precautionary principle. This is expressed most notably the demand by the Clean Ocean Foundation for a commitment to "close ocean outfalls" within 10 years.

The idea that there is a single water cycle in the real world of the biosphere is a compelling intellectual reason for bringing the two water campaigns and water constituencies together and provides an impulse to coordinate with each other in 
shaping policy change. In particular, the community campaign may have some lessons for the elite science campaign on how to affect public policy.

When faced by seemingly transfixed water authorities, the Clean Ocean Foundation responded by instead lobbying the political authorities that could direct the water agencies. The Foundation used a mixture of traditional and highly innovative strategies to put the issue on the agenda. It worked on a marginal seat strategy in state and federal elections to mobilise support in both major political parties, while making sure the Greens and environmental parties were on message, as some of these groups had been slow to prioritise the issue. It linked local community events to the campaign and enlisted support of wine growers, vegetable growers, singers, and advertisers. It secured pro bono support from major advertising and billboard companies and featured a dramatic giant billboard with 'floating Nemo' above Melbourne's major southbound highway, in which a clown fish of uncanny likeness to a Disney creation was depicted floating in polluted water. It ran an information rich website and regular enews. It conducted public education campaigns through the purchase of a police "booze bus" converted into an "ooze bus", full of interactive displays on the reality and risks of outfalls. When running low on funds it asked twelve significant Australian artists to contribute to a fundraiser by painting on surfboards, and ran a highly successful auction at Christies, with commission waived.

As a result of its campaigning the Clean Ocean Foundation has achieved major successes with impacts at both the Victorian state and federal level of politics and policy making. The State opposition party (Liberal) accepted the Foundation's policies in full and the State government (Labor) has committed to a multimillion dollar water recycling feasibility study in response to the campaign [12]. The federal opposition (Labor) and the federal Greens have adopted key policy recommendations, and the Howard Governments $\$ 2$ billion Water Trust announced during the 2004 election campaign, included a particular focus on water infrastructure and recycling which the Foundation had influenced, in part through the local federal MP who had become an active member of the Foundation [13].

By contrast, the Wentworth Group of scientists, named inauspiciously after the hotel they met in rather than the vision they pursued, has sought to capture the heights of scientific consensus and operate on policy through the strength of rational argument. Their Blueprint for a National Water Plan was received by the Premiers and the Prime Minister at an inter-governmental meeting. But the policy proposals it has put forward require wider constituencies to secure the government funding commitments that are identified as necessary, and it is not clear how they will build these constituencies. It appears that the reform process they have sought to initiate has yet to gather momentum. Perhaps the report which gives community forces a role in the implementation of the plans and in ensuring 'fairness' will need to involve those groups in ensuring, first, the acceptance of the plan. This would require that such groups 'own' the plan, and to be assured that the water rights system is the means to achieve the objective. 
The Wentworth Group of Concerned Scientists included a single paragraph on recycling waste water in its otherwise extensive report, merely to note some of the targets that have been set by some urban centres. That they touched base with the issue can be seen as conceptually inclusive, but for a group who see themselves advocating "radical and fundamental reform", it is a very light touch in an area where the Group could be setting targets and estimating potential impacts.

The Clean Ocean Foundation established the community-based campaign to close ocean outfalls and invest in hi-tech recycling of all waste water to a standard, suitable for a large variety of agricultural and industrial uses, without health risks to workers, consumers or the public at large. It has sought commitments from political parties to achieve this over a 10 year period, confident that water which is clearly safe for many specific uses can be secured by detailed investigation of water hazards and strong investments in best practice technologies to deal with particular risks. Here the scientific community will need to be fully engaged. At the same time, management of inputs into the system would be directly addressed and alternative waste processes developed for industry, rather than ongoing licenses to use the system never build for such purposes.

Such an investment in recycling is an investment in the essential infrastructure of the society, as essential today as the sewerage system was to the city 100 years ago - and is no more than the unfinished business of the construction of that system. Such investments need to be undertaken by governments as part of their responsibility to the community and cannot be expected to be profit making in the strict commercial sense. But they will create a saleable water output given the water market that is increasingly coming into effect, and this will produce some financial return (and of course user-pays taxes for water treatment is already part of the property tax mix). Public infrastructure investments, which would be well supported by urban populations, can ease the pressure on river systems and assist the affordability of water to farmers, and to environmental buy-backs schemes alike. It is a major contribution towards solving two environmental health risk problems simultaneously.

\section{References}

[1] www.cleanocean.org.

[2] Treatment Plants: Case Study, www.cleanocean.org/index_general. asp? menuid $=040.060 .040$.

[3] Guidelines for environmental management: Uses of reclaimed water, EPA Victoria, http://epanote2.epa.vic.gov.au/EPA/Publications.nsf/d85500a0d7f5f07b4a 2565d1002268f3/64c2a15969d75e184a2569a00025de63/\$FILE/464.2.pdf

[4] Kevekordes, K. \& Clayton, M.N., Development of Hormosira Banksii (Phaeophyceae) embryos in selected components of secondarily-treated sewage effluent. Journal of Phycology, 36(1), pp. 25 -33.

[5] www.uoe.edu.au/eng/cem/research/ozaquarec.html. 
[6] Jordan, A. \& Greenaway, J., Shifting agendas, changing regulatory structures and the 'new' politics of environmental pollution: British coastal water policy 1955-1995. Public Administration, 76(4), pp. 669685, 1998.

[7] Australian Dryland Salinity Assessment 2000, National Land and Water Resources Audit, http://audit.ea.gov.au/ANRA/land/docs/national/Salinity_Contents.html.

[8] The Wentworth Group of Concerned Scientists, Blueprint for a National Water Plan, WWF, Sydney, 2003.

[9] Quiggin, J., Let's clear muddy waters, Australian Financial Review, 22 October 2003.

[10] Quiggin, J., Risk and water management in the Murray-Darling Basin, Murray Darling Program Working Paper: M05\#\$4, Risk and Sustainable Management Group, University of Queensland.

[11] Gleeson, T., Have the environmental scientists got it right this time? On line opinion, www.onlineopinion.com.au/view.asp?article=1182.

[12] Our Water Our Future: Securing Our Water Future Together, Department of Sustainability and Environment, Victoria, Australia, http://www.dse.vic.gov.au/dse/nrenlwm.nsf/LinkView/BF55F9AC10B38 71FCA256EA200255F883018EEC1F535E3A84A2567D7000B1794.

[13] Koutsoukis, J., Gunnamatta priority in push to end ocean outfalls, The Age, August 13, 2004, www.theage.com.au/articles/2004/08/12/1092102596047.html. 